\title{
Impact of Donor Age, Gender and Handling Time on the DNA Concentration Left on Different Surfaces
}

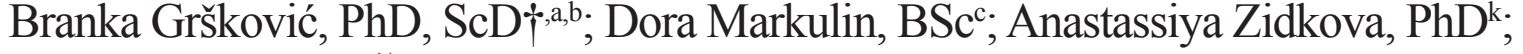 \\ Josip Crnjac, $\mathrm{MSc}^{\mathrm{b}}$; Šimun Anđelinović, $\mathrm{PhD}, \mathrm{ScD}^{\mathrm{b}, \mathrm{f}}$; Inga Marijanović, $\mathrm{PhD}, \mathrm{ScD}^{\mathrm{c}}$; \\ Luka Tomašević, $\mathrm{PhD}, \mathrm{ScD}^{\mathrm{d}, \mathrm{f}}$; Maja Popović, $\mathrm{PhD}, \mathrm{ScD}^{\mathrm{b}, \mathrm{e}}$; Dragan Primorac, $\mathrm{PhD}, \mathrm{ScD}^{\mathrm{f}, \mathrm{gh}, \mathrm{i,j}}$; \\ Gordan Mršić, PhD, $\mathrm{ScD}^{\mathrm{a}, b^{*}}$ \\ ${ }^{a}$ Forensic Science Centre "Ivan Vučetič”, General Police Directorate, Zagreb, Croatia \\ ${ }^{b}$ University Department for Forensic Sciences, University of Split, Split, Croatia \\ ${ }^{c}$ Faculty of Science, University of Zagreb, Zagreb, Croatia \\ ${ }^{d}$ Catholic Faculty of Theology, University of Split, Croatia \\ eDepartment of Biology, University of Zagreb, Zagreb, Croatia \\ ${ }^{f}$ University of Split, Medical School, Split, Croatia \\ ${ }^{g}$ University of Osijek, Medical School, Osijek, Croatia \\ ${ }^{h}$ Eberly College of Science, Penn State University, University Park, PA, USA \\ ${ }^{i}$ University of New Haven, West Haven, CT, USA \\ ${ }^{j}$ Genos Ltd, Zagreb, Croatia \\ ${ }^{k}$ Faculty of Sciences, University of Ostrava, Ostrava, Czech Republic
}

\begin{abstract}
Background: We analyzed the correlation between several factors (donor age and gender, and handling time) and trace DNA concentration that participants left on different surfaces (paper, plastic, plastic coated metal) while holding items in their hands or rubbing them with their fingers, their palms, and the side of the palm of the dominant hand.

Material and Methods: Sixty participants took part in the study. Items were swabbed with a moistened cotton swab. DNA was isolated using the Chelex procedure and quantified by real-time PCR.

Results: We found that DNA concentration transferred to an item was independent of the handling time. On the contrary, it was dependent on the item's texture; the greatest concentration was left on plastic coated metal and the least on paper. The greatest concentration of trace DNA was left by participants from 35 to 44 years of age. Results of the study showed that men deposit a higher DNA concentration than do women.

Conclusion: Item texture, donor age, and gender influence trace DNA concentration. Further investigations are necessary to fully understand the process of DNA transfer from donors to handled items.
\end{abstract}

Key words: forensic analysis; trace DNA; DNA transfer; shedding.

\section{Introduction}

Currently, the analysis of trace DNA is an important direction in crime scene investigation. In forensic casework, geneticists are working every day with trace DNA found on different items [1-3]. As we already know, the duration of contact between a perpetrator and an item is always questionable, depending on the item and the nature of the contact $[4,5]$.

Trace DNA represents a very limited or invisible

*Corresponding Author: Gordan Mršić, PhD, ScD. Forensic Science Centre "Ivan Vučetić"; General Police Directorate, Ministry of Interior; Zagreb, Croatia.E-mail: gmrsic@mup.hr 
biological sample, a small concentration of DNA less than 100 pg [6]. In addition, a trace DNA sample may be defined as any sample which falls below recommended thresholds at any stage of the analysis, from its detection to further analysis and, finally, DNA profiling [7]. DNA can be transferred from palms to an item that someone had held or just touched, even after a short, single skin contact with the item [10-14]. Moreover, it is possible to transfer trace DNA onto a primary surface by palm abrasion and sweating [15]. This process is called shedding and people whose DNA is transferred are called shedders [1517].

It seems that trace DNA has several sources: corneocytes [1], anucleate keratinocytes which contain residual concentration of DNA and are daily sloughed off the skin's surface in large numbers and transferred from palms onto a touched surface by sweat [18], other types of nucleated cells $[2,15,19]$, and sweat that contains cell-free DNA $[3,20]$.

Previous studies have focused mainly on the donor's skin type [14,18,21], item texture [8,10,15,22], handling time $[14,15,19,23]$, activities of the individual prior to contact with an item.

The DNA concentration left on touched items differs from one person to another. However, the exact cause of this difference is still an open question [13]. This suggests that classification of people as good or bad shedders is more difficult than had been thought before. In fact, the same person can act as a good shedder as well as a bad shedder depending on when the person is tested.

It is interesting that trace DNA can be found on items of different textures. DNA profiles have been successfully obtained from touched items such as glass, wood, fabric [10], paper [22], tools, handbag handles [24, 25], as well as knife handles [26].

In order to increase the probability of establishing the identity of a perpetrator, it is necessary to collect as much trace DNA evidence as possible. To achieve this, it is important to recognize items that may contain skin cells, collect them as evidence and use proper sampling methods for optimal recovery of skin cells [27]. If a person who committed a crime left a sufficient number of DNA-bearing cells that can be successfully analyzed, the DNA profile might link the person who committed the crime to the crime scene.

The aim of this study was to analyze the concentration of DNA left by participants on items of different textures (paper, plastic, plastic coated metal), while rubbing with fingers and palm or holding items in a hand, and to find a correlation between that concentration and the handling time, donor age and gender.

Furthermore, the major goal of this investigation was to identify the extent to which trace DNA concentrations depend on different textures. Studies like this are necessary to give an insight into what forensic geneticists could expect while working with trace DNA on different handled items. One thing we should always keep in mind is that we are still unable to identify a person who was last in contact with a specific item, because of the specific nature of DNA transfer. Therefore, results of this research could be used to improve future crime scene investigations.

\section{Material and Methods}

The study included 60 participants (30 men and 30 women). All participants gave their informed consent prior to the beginning of the study. Each participant touched nine items; therefore, the total number of samples was 540 . The participants were divided into three groups according to gender and age: Group 1 consisted of participants between 25 and 34 years of age, Group 2 between 35 and 44 years, and Group 3 between 45 and 54 years. The lowest and the highest range of participants' age was also included. The participants were not related. The study was approved by the Ethics Committee of University of Split and Medical School of Split (Croatia).

\section{Sample preparation}

Participants were asked not to wash their hands several hours prior to testing $[17,18]$. After their arrival, participants were asked to put on powder-free nonsterile disposable gloves (Vinyl 2000 PF, Meditrade) for five minutes on their dominant hand to get it sweaty [17]. UV irradiated cotton swabs were moistened with autoclaved distilled deionized water (Sarstedt, Germany), while the cotton part was cut with scissors and transferred into an Eppendorf tube. To prevent contamination, negative control was prepared using cotton swabs moistened with autoclaved distilled deionized water. The cotton part was also cut with scissors and transferred into an Eppendorf tube, which was left open in the working area during the whole process of sampling.

Three different items were included in the study: white office paper (paper; Catriere Miliani Fabriano S. p. A., Italy), plastic CD boxes (plastic; MS, China), and plastic coated metal bottles (plastified metal; Phosphatesmo KM bottles, Macherey-Nagel, Germany). All items were UV irradiated for 30 minutes. On each paper, three rectangles were drawn equally. Plastic CD boxes were unused and packed, while stickers were removed from the Phosphatesmo KM bottles to get a smooth surface. Every participant had to rub a designated rectangle on the paper, a CD box, and plastic coated metal bottles for one, two, and five minutes. For each time interval, a different item was used. The fingers, the palm, and the side of the palm of the dominant hand were used in rubbing movements. All used items were swabbed with a sterile moistened cotton swab after each time interval. Autoclaved distilled deionized water was used as a moistening agent. After swabbing, the cotton part of the swab was cut with scissors and transferred into an Eppendorf tube. Negative control and each cotton part of the swabs were then subjected to DNA isolation.

\section{DNA analysis}

Genomic DNA was extracted from the cotton part of the swabs using Chelex [28]. After isolation, genomic DNA concentrations in each sample were determined by quantitative real-time PCR using the Quantifiler ${ }^{\mathrm{TM}}$ Human DNA Quantification kit (Applied Biosystems, Foster City, California, USA). Quantitative real-time PCR was performed on a 7500 Real-Time PCR System (Applied Biosystems). The results were analyzed by the absolute quantification method. After quantification, each sample was verified for the presence 
of inhibitors. All the samples from all participants included in this study were destroyed after determination of DNA concentration.

\section{Statistical analysis}

All variables in the study were tested on normality using Shapiro-Wilks test. Null hypothesis in this test was that data have normal distribution; significance value was set to $P=0.004$ after Bonferroni correction. According to the results of normality testing, analysis with nonparametrical tests was performed. For analysis of dependent samples (measurements were performed on the same group of participants), such as DNA concentration comparison according to item texture, the Wilcoxon signed-rank test was used. The Friedman test was used to compare DNA concentration according to the handling time. For comparison of measurements made on independent samples, Mann-Whitney and Kruskal-Wallis were applied. The Mann-Whitney test was used to compare DNA concentration divided by gender. The Kruskal-Wallis test was performed on measurements of DNA concentration divided according to the age group. Those comparisons that yielded significant results in the Kruskal-Wallis test were then tested using a post-hoc Mann-Whitney test with built-in Bonferroni correction. For Friedman and Kruskal-Wallis tests, 2 degrees of freedom were determined. All computation was performed using $\mathrm{R}$ language [29].

\section{Results}

The total number of samples was 540 since 60 participants were included in this study. Every participant was tested nine items. Real-time PCR results showed that from the total number of 540 samples analyzed in this study, a DNA concentration of $0.06 \mathrm{ng} / \mu \mathrm{L}$ or higher was detected in only 18 samples. In 133 samples, the DNA concentration was 0 . The remaining 389 samples had DNA concentration in the range from 0 to $0.05 \mathrm{ng} / \mu \mathrm{L}$. Among the samples, 193 were male and 196 female. In four samples (2 female and 2 male), DNA concentration below $0.06 \mathrm{ng} / \mu \mathrm{L}$ was detected. From a total of 18 samples, in 17 male samples DNA concentrations ranged from 0.06 to $0.36 \mathrm{ng} / \mu \mathrm{L}$. Maximum DNA yield in male samples was $426.31 \mathrm{ng}$, and minimum $71.25 \mathrm{ng}$. Interestingly, in one female sample, DNA concentration $0.07 \mathrm{ng} / \mu \mathrm{L}(77.19$ ng) was found.

\section{Item textures}

Three items of different textures were used in this study: paper, plastic (CD box), and plastic coated metal (smooth surface bottle). Results showed that the highest DNA concentration was transferred onto plastic and plastic coated metal, and the least onto paper (Fig.1).

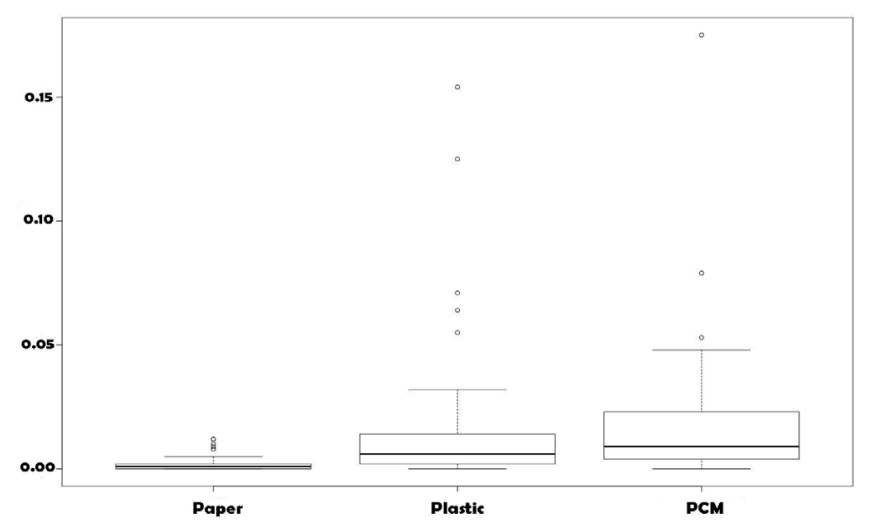

Figure 1. Trace DNA concentration $(n g / \mu L)$ depending on different texture of items (paper, plastic and plastic coated metal bottle)

From 180 analyzed paper surfaces, DNA was detected in $47.8 \%$ cases. The percentage of items on which DNA was detected was higher for plastic and plastic coated metal when compared to $85 \%$ for plastic CD boxes and $93.3 \%$ for a smooth surface.

During contact with the items, individuals left the highest concentration of DNA on plastic coated metal. The median of DNA concentration on plastic coated metal was $0.009 \mathrm{ng} /$ $\mu \mathrm{L}$, while on plastic items it was $0.006 \mathrm{ng} / \mu \mathrm{L}$. The lowest concentration of DNA (the median of DNA concentration - $0.001 \mathrm{ng} / \mu \mathrm{L}$ ) was found on paper (Table 1). A significant difference in DNA concentration was found between paper and plastic as well as between paper and plastic coated metal ( $P$-value $3.001 \times 10^{-13}$ and $3.324 \times 10^{-15}$, respectively), although no statistically significant differences were found between plastic and plastic coated metal $(P=0.018)$.

\section{Donor age}

Results of this study showed that the Group 2 had the highest median DNA concentration $(0.006 \mathrm{ng} / \mu \mathrm{L})$ in comparison to other two groups (Table 1).

\section{Table 1.}

Median concentration of trace DNA samples depending on item texture, donors ' gender, donors ' age and handling time

\begin{tabular}{|c|c|c|c|c|c|c|c|c|c|c|c|c|c|c|c|c|c|c|}
\hline \multirow{3}{*}{ Item texture } & \multicolumn{18}{|c|}{ DNA concentration $(n g / \mu \mathrm{l})$} \\
\hline & \multirow[b]{2}{*}{$\mathrm{Me}$} & \multirow[b]{2}{*}{ IQ } & \multicolumn{4}{|c|}{ Gender } & \multicolumn{6}{|c|}{ Age group } & \multicolumn{6}{|c|}{ Handling time } \\
\hline & & & \multicolumn{2}{|c|}{ Female } & \multicolumn{2}{|c|}{ Male } & \multicolumn{2}{|c|}{1} & \multicolumn{2}{|c|}{2} & \multicolumn{2}{|c|}{3} & \multicolumn{2}{|c|}{$1 \mathrm{~min}$} & \multicolumn{2}{|c|}{$2 \mathrm{~min}$} & \multicolumn{2}{|c|}{$5 \mathrm{~min}$} \\
\hline Paper & 0.001 & 0.002 & 0.001 & 0.001 & 0.001 & 0.002 & 0.000 & 0.001 & 0.001 & 0.002 & 0.002 & 0.003 & 0.000 & 0.002 & 0.000 & 0.002 & 0.000 & 0.002 \\
\hline Plastic & 0.006 & 0.012 & 0.004 & 0.007 & 0.013 & 0.015 & 0.005 & 0.009 & 0.007 & 0.010 & 0.006 & 0.019 & 0.006 & 0.015 & 0.001 & 0.014 & 0.005 & 0.013 \\
\hline All textures & 0.005 & 0.010 & 0.004 & 0.006 & 0.010 & 0.015 & 0.005 & 0.010 & 0.007 & 0.008 & 0.005 & 0.013 & 0.007 & 0.011 & 0.005 & 0.009 & 0.005 & 0.009 \\
\hline
\end{tabular}

Me-Median; IQ (Interquartile Range) = third quartile - first quartile; PCM-plastic coated metal. 
Median DNA concentration for this group was 0.006 $\mathrm{ng} / \mu \mathrm{L}$, and the highest DNA concentration was detected on plastic coated metal $(0.009 \mathrm{ng} / \mu \mathrm{L})$. Groups 1 and 3 both had median DNA concentrations of $0.005 \mathrm{ng} / \mu \mathrm{L}$. There was no significant difference between the DNA concentrations transferred by donors of different ages onto plastic coated metal $(P=0.676)$. Consequently, the Kruskal-Wallis test was performed, in which concentrations of trace DNA were divided according to item texture and donor age. Only the $P$-value for comparison of DNA concentration on paper by donor age was significant $(P=0.030)$. For this comparison, a post-hoc test (Mann-Whitney test) was applied. This test revealed only one significant $P$-value between Group 1 and Group $3(P=0.031)$.

\section{Donor gender}

DNA concentration detected on samples left by men was $0.010 \mathrm{ng} / \mu \mathrm{L}$, while women left only $0.004 \mathrm{ng} / \mu \mathrm{L}$. A significant difference in the DNA concentration transferred onto items of all textures was found between men and women $(P=0.006)$ (Table 1$)$.

We show that men left higher DNA concentrations than women on all textures, except for paper, where no statistically significant result was obtained $(P=0.803)$. A statistically significant difference between men and women was detected in trace DNA concentrations deposited on plastic $(P=0.005)$ and plastic coated metal $(P=0.001)$ (Table 2$)$.

\section{Table 2.}

Results of median DNA concentrations comparison depending on item texture, gender, age group and handling time

\begin{tabular}{|c|c|c|}
\hline Comparison & Test value & $P$-value \\
\hline \multicolumn{3}{|c|}{ Item texture } \\
\hline Paper and plastic & -6.25 & $3.001 \times 10^{-13}$ \\
\hline Paper and plastic covered metal & -6.511 & $3.001 \times 10^{-15}$ \\
\hline Plastic and plastic covered metal & -1.569 & 0.118 \\
\hline \multicolumn{3}{|c|}{\begin{tabular}{|c|} 
Donor's gender \\
\end{tabular}} \\
\hline Paper by gender & -0.250 & 0.803 \\
\hline Plastic by gender & -2.787 & 0.005 \\
\hline Plastic covered metal by gender & -3.180 & 0.001 \\
\hline All textures by gender & -2.752 & 0.006 \\
\hline \multicolumn{3}{|l|}{ Donor's age } \\
\hline Paper by age & 6.992 & $\mathbf{0 . 0 3 0}$ \\
\hline Plastic by age & 1.479 & 0.477 \\
\hline Plastic covered metal by age & 0.784 & 0.676 \\
\hline All textures by age & 0.685 & 0.710 \\
\hline \multicolumn{3}{|c|}{ Handling time } \\
\hline Paper by handling time & 0.259 & 0.879 \\
\hline Plastic by handling time & 0.064 & 0.968 \\
\hline Plastic covered metal by handling time & 2.929 & 0.231 \\
\hline All textures by handling time & 0.028 & 0.986 \\
\hline
\end{tabular}

Note: significant values are written in bold.

\section{Handling time}

All participants handled items of various textures during three time intervals (one, two and five minutes). Results of the relation between handling time and item texture on trace
DNA concentration are listed in Table 1. The highest DNA concentration was detected on plastic coated metal for all three handling times $(0.010,0.008$ and $0.009 \mathrm{ng} / \mu \mathrm{L}$ for one, two and five minutes, respectively).

Comparison of all item textures did not reveal statistically significant differences among medians of DNA concentration for different handling times $(P>0.231)$.

\section{Discussion}

In this study we confirmed that DNA can be transferred from the palms of individuals to items of various textures during contact, which is consistent with previous studies $[8,10,14,15,22,28]$. Moreover, we confirmed that different textures contained different concentrations of donordependent trace DNA. According to DNA quantification results, we assumed that most of our participants were bad shedders because in 137 samples the DNA concentration was undetectable.

On plastic CD and plastic coated metal bottles, a higher DNA concentration was found, when compared to the paper items. Therefore, we can assume that plastic CD boxes and plastic coated metal bottles are suitable for leaving DNA during contact since the highest DNA concentration was left on these items. There was a significant difference between the concentrations of DNA left on the paper and plastic and on the paper and plastic coated metal, but not between the plastic and plastic coated metal, possibly due to the differences in texture of paper and plastic.

We supposed that the low DNA concentration on paper was a result of corneocytes (but also other cell types) transferred onto paper surfaces via sweat and then possibly blown off the paper by mechanical movements of the hand while rubbing a paper. The cause of low DNA concentration on paper could also be due to different chemical bonds between DNA molecules and paper, when compared to plastic and plastic coated metal. Furthermore, paper absorbs sweat, so the swabbing technique may not be the appropriate one for collecting a sufficient concentration of cell-free DNA. Hence, for future research it would be more useful to cut paper into small pieces and then perform DNA isolation. The reason is that paper absorbs sweat and DNA is present in sweat. Performing this kind of isolation, would increase the total DNA concentration. Assuming that plastic does not absorb sweat, a higher DNA concentration could be expected for two reasons. Firstly, corneocytes might be blown off the touched surface by mechanical movements of the hand. In this case, sweat could partially prevent this, because it keeps plastic moistened. Secondly, DNA present in the sweat may contribute to research results. The mechanism by which cell-free DNA diffuses into sweat is still unknown. Scientists suggest that the mechanism could be similar to excretion of metabolites into sweat via sweat ducts. The DNA concentration in sweat has shown intraindividual and interindividual variation, indicating that various factors affect the DNA concentration deposited on the touched item [20].

The highest concentration of trace DNA was found on plastic coated metal bottles that were held in a dominant hand. 
Holding a bottle with the entire palm induced intense palm sweating, leaving the highest concentration. In this study, we applied a fresh transfer of skin cells to a plastic material; therefore, the transfer rate was higher. These results are in concordance with those published previously [30]. Goray et al. [30] showed also that dried transfer has lower transfer rates both on nonporous and porous surfaces (cotton). The fresh transfer rate of skin cells was double when pressure was applied, in comparison to passive contact. In addition, the friction could even further increase transfer rates [30].

Nevertheless, a study that included 20 participants between 23 and 94 years of age showed that participants under 40 years left a higher DNA concentration on the tested surface [31]. On the contrary, our results showed that participants between 35 and 44 years of age left the highest DNA concentration. The lowest DNA concentration was left by participants between 25 and 34 years of age. These findings were supported by significant differences in DNA concentration left on paper, between Group 1 and Group 3 , although the $P$-value was close to the significance level $(P=0.05)$. Other comparisons did not yield statistically significant differences in DNA quantity.

We could argue that participants between 35 and 44 years of age left the highest DNA concentration because they sweat more than others, or their skin was drier in comparison to younger ones. For any further conclusions, it is necessary to perform additional studies, which will investigate the cause of increased sweating (e.g. physical activity prior to testing, nitrition, donor health condition) $[18,20,32-34]$ or the cause of increased loss of skin cells, such as atopic dermatitis or psoriasis $[18,34]$. Furthermore, the number of participants per age group should be also increased for more reliable results. The concentration of trace DNA for separate textures was not in concordance with previous results. A statistically significant difference was not found between the concentrations of trace DNA among different donor age groups. Therefore, it is necessary to perform additional studies to investigate the cause of different concentrations of trace DNA left on handled items by individuals of different age groups.

The only limitation of this study is lack of STR typing. However, this was not the aim of this study.

The results of previous studies investigating the correlation between concentration of trace DNA and donor gender were contradictory. Raymond et al.[23] showed that women left more DNA than men, but the difference between them was not statistically significant. On the contrary, Lowe et al.[13] found that there was no male-versus-female bias in determining the shedder status of an individual, and results were not statistically significant. Furthermore, a recent study conducted by Daly et al.[10], which included 300 participants, showed no statistically significant difference in concentration of trace DNA left by men and women.

Statistically significant results of our study indicated that men leave a higher DNA concentration on touched items than do women. One of the explanations could be that men have a larger palm area, resulting in a larger concentration of cells being shed per square millimeter of skin. It is also possible that men excrete larger concentrations of sweat from sweat glands in the skin of the palm. Mehnert et al.[35] showed that men excrete more sweat than women. In addition, that men exert a greater force of contact could have caused the greater DNA concentration that men left on objects. Men left a higher DNA concentration on plastic and plastic coated metal when compared to women, but not on paper. Although women left more DNA on paper, the difference in concentration of trace DNA between men and women was not statistically significant. We can conclude, then, that in general men leave more DNA on handled items than do women. Here we have to emphasize that 30 men and 30 women were included in the study.

Van Oorschot and Jones [14] showed that the DNA concentration on items held by participants for different time intervals did not differ significantly. These results indicated that transfer of DNA occurs during the initial contact $[14,15,18]$. On the other hand, Raymond et al.[23] pointed out a positive correlation between the trace DNA concentration and handling time. Based on our results, it could be concluded that DNA concentration transferred onto items with different textures was independent of the contact time. A possible explanation of these results could be that the donor left the majority of DNA during one minute.

In conclusion, results of our study showed that DNA concentration was lower on paper than on plastic and plastic coated metal [36]. This could be caused by the structure of paper or by swabbing technique. We also found that men tend to leave greater DNA concentrations than do women. However, we did not prove the effect of handling time and age on the concentration of detected DNA.

Further studies are needed to discover the impact of interindividual and intraindividual variability on the DNA concentration left on various items.

\section{Competing interests}

The authors declare that they have no competing interests.

\section{Grants}

This study was funded by the Ministry of the Interior of Croatia and Ministry of Science, Education and Sports of the Republic of Croatia (141-2160800-0333; 258-2160800-0333).

\section{Acknowledgments}

We thank to Ivana Boričević, BSc, Marija Valić, BSc and Marina Plivelić BSc for technical support.

\section{References}

1. Gršković B, Zrnec D, Vicković S, Popović M, Mršić G. DNA methylation: the future of crime scene investigation? Mol Biol Rep 2013; 40(7):4349-60.

2. Gršković B, Zidkova A, Stenzl S, Popović M, Primorac D, Mršić G. Analysis of 8 X-chromosomal markers in the population of central Croatia. Croat Med J 2013; 54(3):23847.

3. Mršić G, Gršković B, Vrdoljak A, Popović M, Valpotić I, Anđelinović Šs, et al. Croatian national reference Y-STR haplotype database. Mol Biol Rep 2012; 39(7):7727-41. 
4. Gršković B, Zrnec D, Popović M, Petek MJ, Primorac $\mathrm{D}$, Mršić G. Effect of ultraviolet $\mathrm{C}$ radiation on biological samples. Croat Med J 2013; 54(3):263-71.

5. Primorac D, Schanfield M, editors. Forensic DNA Applications: An Interdisciplinary Perspective. 1st ed. New York: CRC Press Taylor and Francis Group; 2014.

6. Gill P. Application of low copy number DNA profiling. Croat Med J 2001; 42(3):229-32.

7. Van Oorschot RAH, Ballantyne KN, Mitchell RJ. Forensic trace DNA: a review. Investig Genet 2010; 1(1):1-14.

8. Balogh MK, Burger J, Bender K, Schneider PM, Alt KW. STR genotyping and $\mathrm{mtDNA}$ sequencing of latent fingerprint on paper. Forensic Sci Int 2003; 137(2-3):188-95.

9. Butler JM. Fundamentals of forensic DNA typing. Elsevier Academic Press, San Diego; 2010.

10. Daly DJ, Murphy C, McDermott SD. The transfer of touch DNA from hands to glass, fabric and wood. Forensic Sci Int Genet. 2012; 6(1):41-6.

11. Djuric M, Varljen T, Stanojevic A, Stojkovic O. DNA typing from handled items. Forensic Sci Int Genet Suppl Ser 2008; 1:411-2.

12. Kita T, Yamaguchi H, Yokoyama M, Tanaka T, Tanaka N. Morphological study of fragmented DNA on touched objects. Forensic Sci Int Genet 2008; 3(1):32-6.

13. Low A, Murray C, Whitaker J, Tully G, Gill P. The propensity of individuals to deposit DNA and secondary transfer of low level DNA from individuals to inert surfaces. Forensic Sci Int 2002; 129(1):25-34.

14. Van Oorschot RAH, Jones MK. DNA fingerprints from fingerprints. Nature. 1997; 387(6635):767.

15. Wickenheiser RA. Trace DNA: a review, discussion of theory, and application of the transfer of trace quantities of DNA through skin contact. J Forensic Sci 2002; 47(3):442-50.

16. Farmen RK, Jaghø R, Cortez P, Frøyland ES. Assessment of individual shedder status and implication for secondary DNA transfer. Forensic Sci Int Genet Suppl Ser 2008; 1: 415-7. 17. Phipps M, Petricevic S. The tendency of individuals to transfer DNA to handled items. Forensic Sci Int 2007; 168(2-3):162-8. 18. Alessandrini F, Cecati M, Pesaresi M, Turchi C, Carle F, Tagliabracci A. Fingerprints as evidence for a genetic profile: Morphological study on fingerprints and analysis of exogenous and individual factors affecting DNA typing. J Forensic Sci 2003; 48:586-92.

19. Duke-Elder S. System of ophthalmology, Vol. II: The anatomy of the visual system. Henry Kimpton Publishers, London; 1976.

20. Quinones I, Daniel B. Cell free DNA as a component of forensic evidence recovered from touched surfaces. Forensic Sci Int Genet 2012; 6(1):26-30.

21. Bright JA, Petricevic SF. Recovery of trace DNA and its application to DNA-profiling of shoe insoles. Forensic Sci Int
2004; 145(1):7-12.

22. Sewell J, Quinones I, Ames C, Multaney B, Curtis S, Seeboruth H, et al. Recovery of DNA and fingerprints from touched documents. Forensic Sci Int Genet 2008; 2(4):281-5. 23. Raymond JJ. A criminalistic approach to biological evidence: Trace DNA and volume crime offences. Dissertation, University of Technology; 2010.

24. Van Hoofstat DE, Deforce DL, Hubert De Pauw IP, Van den Eeckhout EG. DNA typing of fingerprints using capillary electrophoresis: effect of dactyloscopic powders. Electrophoresis 1999; 20(14):2870-6.

25. Van Renterghem P, Leonard D, De Greef C. Use of latent fingerprints as a source of DNA for genetic identification. Prog Forensic Genet 2000; 8:501-3.

26. Wickenheiser RA, Challoner CM. Suspect DNA-profiles obtained from the handles of weapons recovered at crime scenes. The Tenth Int Symposium on Human Identification. Promega Corporation, Madison; 1999.

27. Williamson AL.Touch DNA: forensic collection and application to nvestigations. J Assoc Crime Scene Reconstr 2012; 18(1):1-5.

28. Walsh PS, Metzger DA, Higuchi R.Chelex 100 as a medium for simple extraction of DNA for PCR-based typing from forensic material. Biotechniques 1991; 10(4):506-13.

29. Ithaka, Gentelman R. R: A language for data analysis and graphics. J Comput Graph Stat 1996; 5(3):299-314.

30. Goray M, Mitchell RJ, van Oorschot RAH. Investigation of secondary DNA transfer of skin cells under controlled test conditions. Leg Med (Tokyo) 2010; 12(3):117-20.

31. Raymond JJ, van Oorschot RAH, Walsh SJ, Roux C, Gunn P. Trace DNA and street robbery: a criminalistic approach to DNA evidence. Forensic Sci Int Genet Suppl Ser 2009; (2):544-6.

32. Butt AN, Swaminathan R. Overview of circulating nucleic acids in plasma/serum. Ann N Y Acad Sci 2008; (1137):23642.

33. Freedberg IM, Eisen AZ, Wolff K, Austen KF, Goldsmith LA, Katz, SL. Fitzpatrick's Dermatology in general medicine, 6th ed. McGraw-Hill Professional, New York; 2003.

34. Kamphausen T, Schadendorf D, von Wurmb-Schwark N, Bajanowski T, Poetsch M. Good shedder or bad shedderthe influence of skin diseases on forensic DNA analysis from epithelial abrasions. Int J Legal Med 2012; 126(1):179-83.

35. Mehnert P, Bröde P, Griefahn B. Gender-related difference in sweat loss and its impact on exposure limits to heat stress. Int J Ind Ergon 2002; 29:343-51.

36. Markulin D, Gršković B, Marijanović I, Popović M, Primorac D, Mršić G. Relation of touch DNA from different surfaces with donor age and gender. The eighth ISABS conference in forensic, anthropologic and medical genetics and Mayo Clinic lectures in translational medicine. 2013; 164. 